BMC

Microbiology

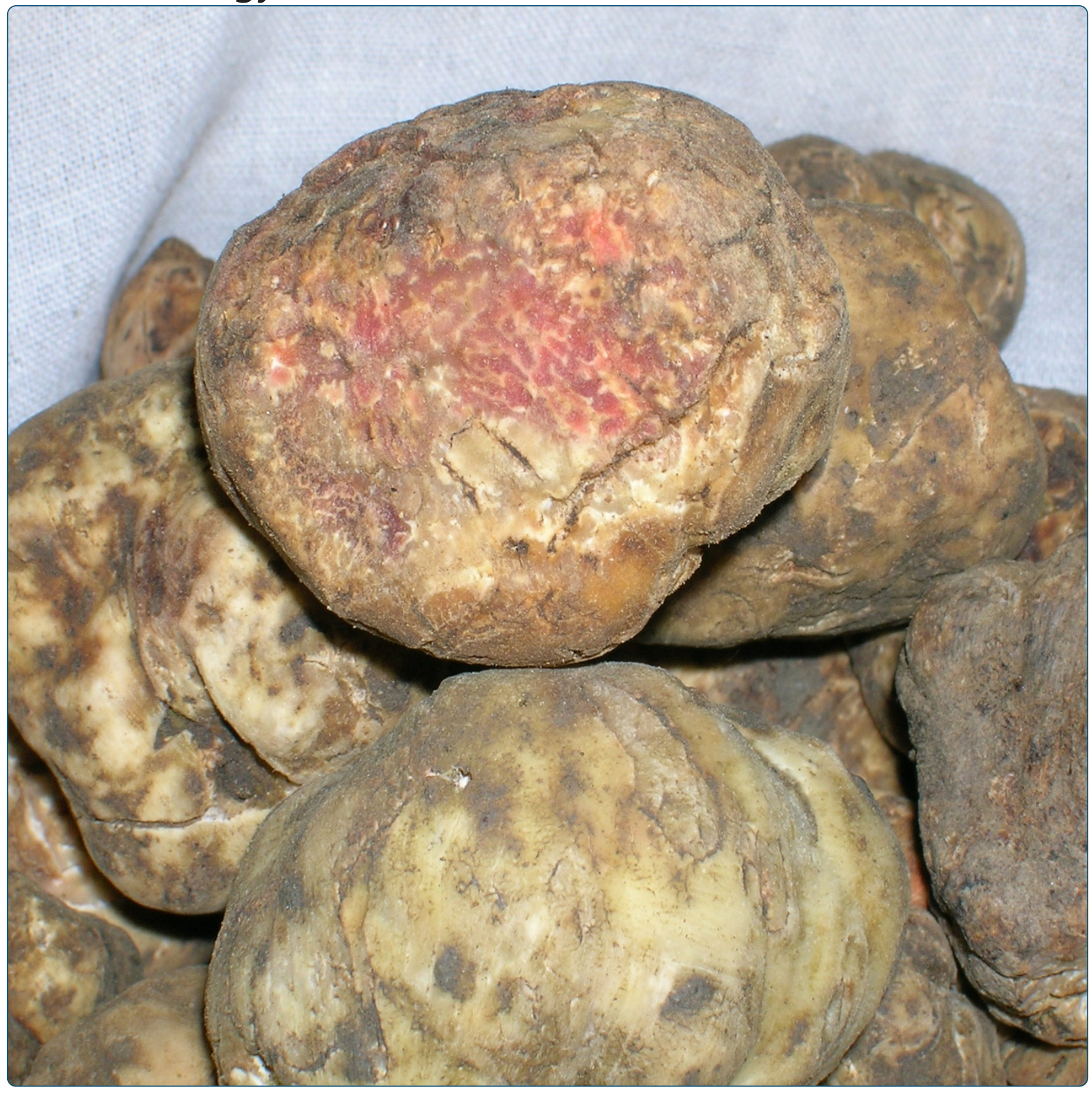

Development and validation of a real-time PCR assay for detection and quantification of Tuber magnatum in soil

lotti et al.

C Biomed Central

lotti et al. BMC Microbiology 2012, 12:93

http://www.biomedcentral.com/1471-2180/12/93 


\title{
Development and validation of a real-time PCR assay for detection and quantification of Tuber magnatum in soil
}

\author{
Mirco lotti ${ }^{1}$, Marco Leonardi ${ }^{2}$, Marilena Oddis ${ }^{2}$, Elena Salerni ${ }^{3}$, Elena Baraldi ${ }^{1}$ and Alessandra Zambonelli ${ }^{1 *}$
}

\begin{abstract}
Background: Tuber magnatum, the Italian white truffle, is the most sought-after edible ectomycorrhizal mushroom. Previous studies report the difficulties of detecting its mycorrhizas and the widespread presence of its mycelium in natural production areas, suggesting that the soil mycelium could be a good indicator to evaluate its presence in the soil. In this study a specific real-time PCR assay using TaqMan chemistry was developed to detect and quantify T. magnatum in soil. This technique was then applied to four natural T. magnatum truffières located in different regions of Italy to validate the method under different environmental conditions.
\end{abstract}

Results: The primer/probe sets for the detection and quantification of T. magnatum were selected from the ITS rDNA regions. Their specificity was tested in silico and using qualitative PCR on DNA extracted from 25 different fungal species. The T. magnatum DNA concentration was different in the four experimental truffières and higher in the productive plots. T. magnatum mycelium was however also detected in most of the non-productive plots. Ascoma production during the three years of the study was correlated with the concentration of T. magnatum DNA.

Conclusions: Taken together, these results suggest that the specific real-time PCR assay perfected in this study could be an useful tool to evaluate the presence and dynamics of this precious truffle in natural and cultivated truffières.

Keywords: Real-time PCR, Taq-man probe, Tuber magnatum DNA concentration, Soil DNA extraction, ITS primers, Truffle production

\section{Background}

Truffles are hypogeous ectomycorrhizal Ascomycetes belonging to the order Pezizales. The most sought-after species belong to the Tuber genus and include Tuber melanosporum Vittad. (Périgord black truffle), Tuber magnatum Pico (Italian white truffle), Tuber aestivum Vittad. (Burgundy truffle) and Tuber borchii Vittad. (bianchetto). Amongst these the Italian white truffle commands the highest prices. This truffle grows in many regions of Italy: from Piedmont in the north, where Alba is the most famous production area, to Basilicata in the extreme south of Italy [1]. It is also found in Croatia and has recently been found, although in small quantities, in Romania, Serbia, Hungary and Slovenia [2-4].

\footnotetext{
* Correspondence: zambonel@agrsci.unibo.it

'Dipartimento di Protezione e Valorizzazione Agroalimentare, Alma Mater Studiorum Università di Bologna, via Fanin 46, 40127, Bologna, Italy Full list of author information is available at the end of the article
}

Methods have been developed to produce T. magnatum infected trees using spore inoculation techniques [5-7] or root organ cultures [8]. However, while some successes are reported [9] in general attempts to cultivate this truffle species have met with failure $[1,10,11]$. This failure to produce T. magnatum fruiting bodies from cultivated plots has been compounded by falling harvests from natural truffières, attributed to deforestation, changing forest management practices, global warming since the last ice age as well as acid rain [12]. These factors have spurred efforts to carry out research aimed at safeguarding T. magnatum production in natural truffières and developing tools to evaluate their state of "health".

In contrast to the other truffles such as T. melanosporum, T. aestivum and T. borchii, which are comparatively easy to cultivate, $T$. magnatum mycorrhizas are scarce or absent even where their ascomata are found $[13,14]$. On the other hand, recent studies have shown

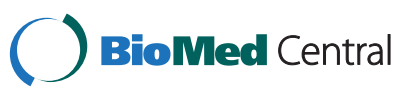


that T. magnatum mycelium is widely distributed in the soil of truffières and its presence is not restricted to just those points where mycorrhizas or ascomata are found [15]. These observations suggest that T. magnatum soil mycelium could be a better indicator than mycorrhiza for assessing its presence in the soil.

DNA-based techniques have been extensively applied to study fungal ecology in soil [16]. Recently, real-time PCR has made it possible not only to detect and monitor the distribution of a particular fungus but also its abundance [17-20]. Knowledge of the distribution, dynamics and activities of Tuber spp. mycelium in soil can be considered crucial for monitoring the status of a cultivated truffle orchard before ascoma production [21]. It is also a powerful tool for assessing truffle presence in natural forests in those countries where ascoma harvesting is forbidden [22] or where all truffle collectors have open access to forests and woodlands [1]. This is particularly important for T. magnatum as the truffle production sites, in natural truffières, are dispersed and not visible to the naked eye, unlike black truffles (T. melanosporum and $T$. aestivum) which produce burnt areas (called "brûlée" in France, "bruciate" or "pianello" in Italy) around the productive trees where grass development is inhibited [1].

In this study a specific real-time PCR assay using TaqMan chemistry was developed to detect and quantify $T$. magnatum in soil. This technique was then applied to four natural $T$. magnatum truffières in different Italian regions to validate the method under different environmental conditions.

\section{Results and discussion DNA extraction}

Successful application of molecular-based techniques for DNA analyses of environmental samples strongly depends on the quality of the DNA extracted [23]. Moreover, the heterogeneous distribution of fungi in soil with small samples $(<1 \mathrm{~g})$ can lead to an unrepresentative fungal fingerprinting [24]. For this reason total DNA was isolated from $15 \mathrm{~g}$ of lyophilized soil for each plot (3 sub-samples of $5 \mathrm{~g}$ each), selected from about $60 \mathrm{~g}$ of sampled soil from each plot, using a procedure specifically developed to obtain good quality extracts regardless of the different soil types analysed in this study. To obtain equal $3 \mathrm{ml}$ solutions of crude DNA from the different soils we had to process samples from Emilia-Romagna/Tuscany and Molise/Abruzzo truffle areas with different quantities of CTAB lysis buffer (6 and $7 \mathrm{ml}$ respectively) at the beginning of the extraction step. A total of 351 extractions (3 replicates per 117 soil samples) were successfully carried out using this improved method. The mean quantity of DNA isolated from samples processed in this study range from 2.2 to $7.0 \mu \mathrm{g} \mathrm{g}^{-1}$ of soil for the Molise and Tuscan truffières respectively.

ANOVA was performed to determine whether the quantities of DNA isolated from the sampled soil varied in the different truffières. The data reveal significant differences $(p \leq 0.05)$ between DNA isolated from the soil samples of the different truffières (Table 1). The lowest values were obtained from samples collected in the Molise and Abruzzo truffières. This may be due to the higher clay content in the soil of these two experimental truffières. Indeed, DNA extraction is difficult for soils containing clay $[25,26]$ and DNA adsorption and desorption is strongly affected by the clay type and content [27]. Other factors such as climate, soil, and vegetation conditions may however also contribute to modifying microbial activity below ground and consequently the quantity of total DNA isolated.

Mean values of the $\mathrm{OD}_{260 / 280} \mathrm{~nm}$ and $\mathrm{OD}_{260 / 230 \mathrm{~nm}}$ ratios calculated for each truffière range from 1.73 to 1.77 and from 1.65 to 1.71 respectively.

\section{Primer and probe selection}

The ITS regions were chosen to develop an appropriate primer/probe set for the detection and quantification of T. magnatum. The use of these genomic regions as the

Table 1 Mean values and statistics of soil DNA extractions and real time PCRs

\begin{tabular}{|c|c|c|c|c|c|c|c|c|}
\hline \multirow[t]{3}{*}{ Truffière locality (region) } & \multicolumn{3}{|l|}{ Soil DNA extraction ${ }^{1}$} & \multirow[t]{3}{*}{ PP/TNP } & \multicolumn{4}{|l|}{ Real time data $^{1}$} \\
\hline & \multirow[t]{2}{*}{ quantity ( $\mu \mathrm{g} \mathrm{g}^{-1}$ soil) ${ }^{2}$} & \multirow[t]{2}{*}{$\mathrm{OD}_{260 / 230 \mathrm{~nm}}$} & \multirow[t]{2}{*}{$O D_{260 / 280 \mathrm{~nm}}$} & & \multirow[t]{2}{*}{ plot with TM-DNA/TNP } & \multicolumn{3}{|c|}{ TM-DNA concentration ${ }^{3}$} \\
\hline & & & & & & Whole $^{2}$ & PP & $\mathrm{NPP}^{4}$ \\
\hline Feudozzo (A) & $3.4 \mathrm{a}$ & 1.75 & 1.79 & $6 / 12$ & $12 / 12$ & $8.46 \mathrm{a}$ & 9.85 & 7.08 \\
\hline Collemeluccio (M) & $2.3 \mathrm{a}$ & 1.64 & 1.64 & $1 / 9$ & $5 / 9$ & $0.72 \mathrm{a}$ & 3.12 & $0.03^{*}$ \\
\hline Argenta (ER) & $6.9 \mathrm{~b}$ & 1.81 & 1.83 & $4 / 9$ & $8 / 9$ & $11.76 \mathrm{a}$ & 19.28 & $5.73^{*}$ \\
\hline Barbialla (T) & $7.0 \mathrm{~b}$ & 1.82 & 1.83 & $6 / 9$ & $9 / 9$ & $28.18 \mathrm{~b}$ & 35.41 & 13.71 \\
\hline
\end{tabular}

${ }^{1}$ Mean values referred to three years of experimentation.

${ }^{2}$ Different letters in the same column indicate significant differences between the mean values obtained from different truffières (ANOVA and Bonferroni's test, $p<0.05)$.

${ }^{3} \mathrm{pg}$ of T. magnatum DNA in $200 \mathrm{ng}$ of total DNA.

${ }^{4}$ The asterisk indicates significant differences between the mean TM-DNA concentration of PP and NPP in the same truffière (ANOVA, $p<0.05$ ).

A, Abruzzo; M, Molise; ER, Emilia Romagna; T, Tuscany; OD, optical density; PP, productive plots; NPP, non productive plots; TNP, total number of plots; TM-DNA, T. magnatum DNA. 
Table 2 Primers and probes tested in this study

\begin{tabular}{|c|c|c|c|c|c|}
\hline Primer/Probe & Sequence $\left(5^{\prime}-3^{\prime}\right)$ & Length (bp) & Amplicon (bp) & Target region & GC (\%) \\
\hline TmglTS1for & GCGTCTCCGAATCCTGAATA & 20 & 106 & ITS1 & 50 \\
\hline TmglTS1rev & ACAGTAGTTITTGGGACTGTGC & 22 & & & 45 \\
\hline TmgITS1 prob & TGTACCATGCCATGTTGCTT & 20 & & & 45 \\
\hline TmglTS2for & AAACCCACTCACGGAATCAC & 20 & 99 & ITS2 & 50 \\
\hline TmglTS2rev & CGTCATCCTCCCAATGAAA & 19 & & & 47 \\
\hline TmglTS2prob & GTACCAAGCCACCTCCATCA & 20 & & & 55 \\
\hline
\end{tabular}

target for real time PCR-amplification has proven to be a successful strategy for different ectomycorrhizal fungi in soil $[19,21,28]$. This is due to the large number of sequences available in genetic databases that make ITS regions suitable for designing reliable species-specific primers. Moreover, the presence of multiple copies of

Table 3 Collection numbers and origin of the fungal materials used in this study

\begin{tabular}{|c|c|c|c|}
\hline Species & Source $^{1}$ & CMI-Unibo $^{2}$ herbarium code & Origin (Region, Country) \\
\hline Tuber magnatum Pico & d.A & CMI-Unibo 1182 & Molise, Italy \\
\hline Tuber magnatum Pico & d.A & CMI-Unibo 3990 & Emilia Romagna, Italy \\
\hline Tuber magnatum Pico & d.A & CMI-Unibo 4059 & Marche, Italy \\
\hline Tuber magnatum Pico & d.A & CMI-Unibo 4090 & Romania \\
\hline Tuber magnatum Pico & d.A & CMI-Unibo 4152 & Emilia Romagna, Italy \\
\hline Tuber aestivum Vittad. & d.A & CMI-Unibo 1571 & Marche, Italy \\
\hline Tuber asa Tul. \& C. Tul. & d.A & CMI-Unibo 2124 & Veneto, Italy \\
\hline Tuber borchii Vittad. (type 1) ) $^{3}$ & d.A & CMI-Unibo 2682 & Sicily, Italy \\
\hline Tuber borchii Vittad. (type 2) ) $^{3}$ & d.A & CMI-Unibo 2363 & Veneto, Italy \\
\hline Tuber brumale Vittad. & d.A & CMI-Unibo 1547 & Emilia Romagna, Italy \\
\hline Tuber dryophilum Tul. \& C. Tul. & d.A & CMI-Unibo 1547 & Emilia Romagna, Italy \\
\hline Tuber excavatum Vittad. & d.A & CMI-Unibo 1446 & Emilia Romagna, Italy \\
\hline Tuber indicum Cooke and Massee & d.A & CMI-Unibo 1759 & Yunnan, China \\
\hline Tuber macrosporum Vittad. & d.A & CMI-Unibo 1515 & Emilia Romagna, Italy \\
\hline Tuber maculatum Vittad. & M & Tma1 & Emilia Romagna, Italy \\
\hline Tuber melanosporum Vittad. & M & Tme4 & Marche, Italy \\
\hline Tuber mesentericum Vittad. & d.A & CMI-Unibo 1585 & Emilia Romagna, Italy \\
\hline Tuber oligospermum (Tul. \& C. Tul.) Trappe & d.A & CMI-Unibo 4231 & Marmora forest, Morocco \\
\hline Tuber rufum Pico & d.A & CMI-Unibo 1798 & Emilia Romagna, Italy \\
\hline Terfezia claveryi Chatin & d.A & CMI-Unibo 4231 & Cappadocia, Turkey \\
\hline Choiromyces meandriformis Vittad. & d.A & CMI-Unibo 1432 & Emilia Romagna, Italy \\
\hline Balsamia vulgaris Vittad. & d.A & CMI-Unibo 3460 & Emilia Romagna, Italy \\
\hline Genea klotzschii Berk. \& Broome & d.A & CMI-Unibo 1944 & Emilia Romagna, Italy \\
\hline Ganoderma lucidum (Curtis) P. Karst. & M & Glu5039 & Armenia \\
\hline Hymenogaster luteus Vittad. & d.B & CMI-Unibo 1947 & Emilia Romagna, Italy \\
\hline Valsa ceratosperma (Tode) Maire & M & Vce155 & Emilia Romagna, Italy \\
\hline Cryphonectria parasitica (Murrill) M.E. Barr. & M & Cpa5 & Emilia Romagna, Italy \\
\hline Monilia laxa (Ehrenb.) Sacc. \& Voglino & M & Mla95 & Emilia Romagna, Italy \\
\hline Aspergillus flavus Link & M & Afl7 & Emilia Romagna, Italy \\
\hline Penicillium expansum Link & M & Pex25 & Emilia Romagna, Italy \\
\hline
\end{tabular}

${ }^{1} \mathrm{~d} . \mathrm{A}=$ dried ascoma; $\mathrm{d} . \mathrm{B}=$ dried basidioma; $\mathrm{M}=$ mycelium in pure culture.

$2 \mathrm{CMI}$-Unibo = Center of mycology of Bologna University.

${ }^{3}$ Bonuso et al. [35]. 
rDNA units within each fungal genome also make it possible to detect low quantities of the target DNA [29]. ITS regions are not, however, equally variable in all groups of fungi [30] and this could represent a limitation for designing a specific primer in some species [31]. The alignment of about 70 ITS1-5.8 S-ITS2 T. magnatum sequences retrieved from the GenBank database highlighted a high level of conservation of ITS regions in this species $(0 / 186 \mathrm{nt}$ for ITS1 and 2/217 for ITS2), higher than those found in other truffle species [32-34].

A single primer/probe set was selected for both the ITS1 and the ITS2 region (Table 2) based on in silico analyses of their composition, Tm, PCR-impairing structure formation and specificity against the sequences in GenBank. Both of the primer pairs selected produced specific amplicons of the expected size for all the $T$. magnatum specimens considered in this study and gave no cross-reactions with other fungal species under qualitative PCR conditions (Table 3). Specificity of the probes was also confirmed (data not shown). However, the primers and probe designed from ITS1 were selected for the subsequent real-time PCR analyses, as they provided more efficient amplification (Figure 1). Indeed, the TmgITS1for-TmgITS1rev primer pair allowed detection of the specific amplicon down to dilutions of $1 / 1000$ (0.1 ng of T. magnatum DNA mixed with $100 \mathrm{ng}$ of non-target DNAs), ten fold lower than TmgITS2forTmgITS2rev. The specificity of the ITS1 primer/probe set was also confirmed under real-time PCR conditions for all soil samples processed.

\section{Real time quantification of T. magnatum DNA}

The real-time assay showed reliable amplification over the 6 orders of magnitude generating almost identical standard curves from each run quantifying T. magnatum DNA in soil samples. The correlation coefficients $\left(R^{2}\right.$ values) were always higher than 0.99 and amplification efficiency was about $85 \%$. The mean standard curve resulting from

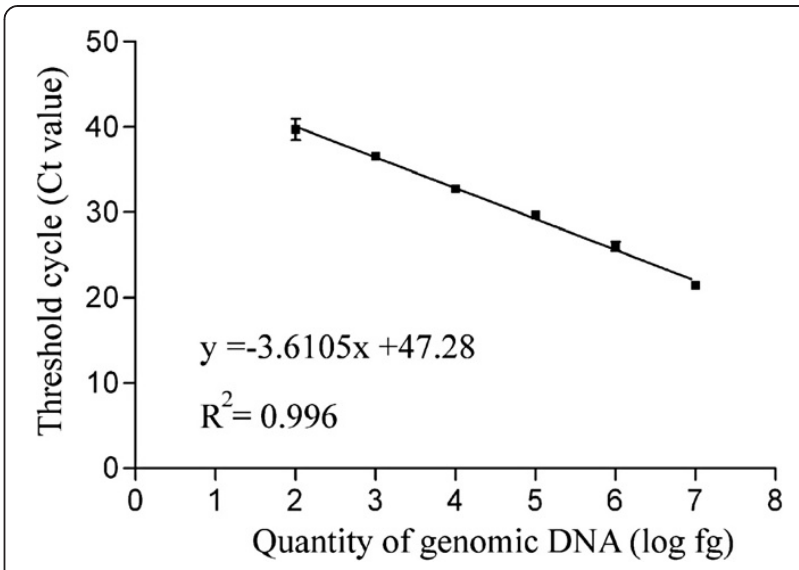

Figure 2 Real-time PCR standard curve for T. magnatum DNA quantification. The curve was generated by plotting the means of the $\mathrm{Ct}$ values obtained against the logarithm of a known quantity of genomic DNA. Variability is shown as the mean Ct value \pm SD.

18 independent plates is shown in Figure 2. The detection limit for real-time PCR with the ITS1 primer/probe set was approximately $10 \mathrm{fg}$. However, since standard replicates containing less than $100 \mathrm{fg}$ of $T$. magnatum DNA gave inconsistent amplifications, to avoid the inclusion of false positive test results, values lower than this threshold were considered as 0 .

\section{Detection of T. magnatum ascomata and DNA}

Truffle production was scattered and localized in only 17 of the 39 plots examined. A total of 74 T. magnatum ascomata, for a total weight of $1184.3 \mathrm{~g}$, were collected over the 3-year period of investigation in the 4 experimental truffières (Additional file 1).

There was a high variation in the concentration of $T$. magnatum DNA detected by real-time PCR in the 117 samples processed, even from the same plot, over the three years of sampling thus confirming that mycelium varies considerably in the soil over time [28]. No

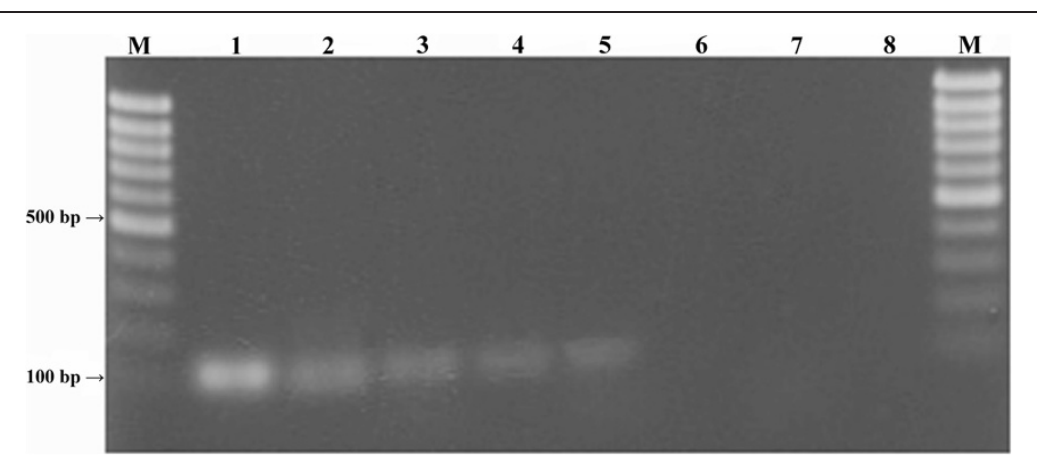

Figure 1 PCR sensitivity of the primer pairs selected from ITS1 and ITS2 regions. Reactions carried out using serial dilutions of $T$. magnatum DNA (TM-DNA) in pooled non-target fungal DNAs (F-DNA): lane M, Mass ruler marker (Fermenats); lanes 1, 3, 5 and 7, ITS1for-ITS1 rev primer pair; lanes 2, 4, 6 and 8, ITS2for-ITS2rev primer pair. Lanes 1-2, 10 ng TM-DNA/90 ng F-DNA; lanes 3-4, 1 ng TM-DNA/99 ng F-DNA; lanes 5-6, 0.1 ng TM-DNA/99.9 ng F-DNA; lanes 7-8, 0.01 ng TM-DNA/99.99 ng F-DNA. 
fluorescence was ever recorded in DNA from the soil samples collected outside the truffière in any of the experimental sites.

The mean concentration of $T$. magnatum DNA detected in the four different truffières was statistically different indicating that environmental condition, such as climate, vegetation, soil chemical and biological characteristics, influence the relative quantity of T. magnatum DNA in the soil (Table 1). The lowest mean concentration of target DNA was associated with the soil samples collected in the Molise truffière. In this experimental site significant amounts of $T$. magnatum DNA were only detected in the unique plot that produced ascomata during the 3 years of the survey. On the contrary, soil samples from the Tuscan truffière showed the highest mean value for DNA concentration and positive real-time amplifications were obtained for all plots. $T$. magnatum DNA was also found in plots that never produced truffles during the three years of the study (Table 1). This can be explained by the fact that, in soil, T. magnatum mycelium is able to develop as far as $100 \mathrm{~m}$ from the production points [15], thus forming large mycelial patches that may colonize other contiguous plots. Higher mean values for T. magnatum DNA concentrations were however obtained from productive plots (Table 1) even if in Tuscany and Abruzzo no significant differences were found between productive and non-productive plots. This is probably due to the high percentage of productive plots of these two truffières where mycelial patches may have overlapped. Despite this, there was a significant correlation $(\mathrm{p}$-level $\leq 0.05)$ between the mean T. magnatum DNA concentration and plot productivity (Spearman's rank correlation coefficients, respectively 0.56 and 0.55 for the number and the weight of ascomata collected in the three years of the study). These results indicate that the production of T. magnatum fruiting bodies is positively related to the presence of mycelium in the soil although the fructification process is limited in space by other factors which are still not clear.

In previous studies of $T$. melanosporum it was found that the presence of a burnt area around a tree infected by $T$. melanosporum was related to the quantity of its mycelium in the soil [20]. These Authors, however, found a higher quantity of the mycelium in nonproductive trees and explained this as a shift in resource allocation by the fungal ascoma. In our study we found the highest quantity of T. magnatum DNA in the productive plots, indicating that this truffle species has a different behaviour in the soil. As T. magnatum mycorrhizas are rare or absent in the productive areas and probably unable to support fruiting body formation, its free live mycelium should provide a sufficient quantity of nutrients to support ascoma formation and successive development. It has already been shown that after their formation in the soil truffle ascomata have a saprobic phase and, during their maturation, become nutritionally independent on the host plant. Probably, in T. magnatum, this saprobic phase is much more important than previously considered and as also suggested by Zampieri et al. [15].

\section{Conclusions}

The results reported here demonstrate that the real-time PCR assay developed in this study can be an effective tool for quantifying T. magnatum in the soil and for monitoring the presence of this precious fungus, regardless of truffle production. This technique could be a useful tool to evaluate the "health" of natural and cultivated truffières and to assess the effect of different cultivation techniques. This aspect is particularly important because in natural truffières ascoma production is dispersed and depends on annual climatic conditions. Thus many years of survey are necessary to evaluate the effects of any new variable. Moreover, it is difficult to assess truffle production in natural truffières because in Italy there is no control of truffle harvesting in the forests and numerous different truffle hunters may visit a single truffière in one day [1].

Real-time PCR will make it possible to carry out further studies on the spatial and seasonal changes in the quantity of T. magnatum mycelium in the soil to gain more knowledge on its biology and ecology.

\section{Methods}

\section{Experimental truffières}

For this study four natural $T$. magnatum truffières located in four different Italian regions (Emilia Romagna, Tuscany, Abruzzo and Molise) were chosen on the basis of their high T. magnatum ascoma productivity. All these truffières are closed to the public so the scientific data on production collected are more meaningful.

The Emilia Romagna experimental truffière is located in the Museum of the Bonifica Renana park at Argenta (Ferrara) (latitude $44^{\circ} 37^{\prime} 10^{\prime \prime} \mathrm{N}$, longitude $11^{\circ} 48^{\prime} 55^{\prime \prime}$ $\mathrm{E}$, altitude $5 \mathrm{~m}$ asl). This truffière is representative of the natural T. magnatum production areas in the Po valley that are mostly located in private or public gardens and parks, the natural indigenous forest having been largely supplanted by agriculture. The putative T. magnatum host plants are poplar (Populus nigra L.) and linden (Tilia vulgaris Hayne). The soil of the truffière is calcareous (10-25\% of total $\left.\mathrm{CaCO}_{3}\right)$ with a $\mathrm{pH}$ ranging from 7.9 to 8.3 in the different plots.

The Tuscany, Abruzzo and Molise experimental truffières are representative of the natural $T$. magnatum truffières in the broad-leaved forests of the Apennine mountains of central-southern Italy. The Tuscan 
truffière is located at Barbialla nuova, Montaione (Florence) (latitude $43^{\circ} 35^{\prime} 30^{\prime \prime} \mathrm{N}$, longitude $10^{\circ} 50^{\prime} 55^{\prime \prime} \mathrm{E}$, altitude $135 \mathrm{~m}$ asl). The putative host plants are hornbeam (Ostrya carpinifolia Scop.), poplar (Populus alba L.) and oaks (Quercus cerris L., Quercus petraea (Mattuschka) Liebl., Quercus ilex L.). The soil has a $\mathrm{CaCO}_{3}$ content ranging from 4 to $10 \%$ and a $\mathrm{pH}$ of 7.7-8.4.

The Abruzzo and Molise truffières are located in two Man \& Biospher reserves managed by the Biodiversity Office of the State Forestry Corps: Feudozzo (Abruzzo) (latitude $41^{\circ} 45^{\prime} 55^{\prime \prime} \mathrm{N}$, longitude $14^{\circ} 11^{\prime} 12^{\prime \prime} \mathrm{E}$, altitude $950 \mathrm{~m}$ asl), and Collemeluccio (Molise) (latitude $41^{\circ} 42^{\prime}$ $07^{\prime \prime} \mathrm{N}$, longitude $14^{\circ} 20^{\prime} 34^{\prime \prime} \mathrm{E}$, altitude $810 \mathrm{~m}$ asl). In both areas there is a large contingent of mesohygrophilous species, favoured by the presence of surface water, probably due to the proximity of small springs. There are many putative host plants in both truffières: at Feudozzo (Abruzzo) poplar (Populus tremula L.), oak (Q. cerris), willow (Salix alba L., Salix apennina Skvortsov, Salix caprea L. and Salix purpurea L.), hornbeam (Carpinus betulus L. and Carpinus orientalis Miller) and hazelnut (Corylus avellana L.); at Collemeluccio (Molise) poplar (P. nigra and P. canadensis L.), oak (Q. cerris), linden (Tilia platyphyllos Scop.), silver fir (Abies alba Miller), hazelnut (C. avellana) and hornbeam (O. carpinifolia). However, all T. magnatum collection occurred beneath $A$. alba. The geological substratum is represented by alternating argillaceous sandstone: at Feudozzo, the soil has a $\mathrm{CaCO}_{3}$ content ranging from 0.75 to $4.20 \%$ and a $\mathrm{pH}$ of 6.8-7.8; at Collemeluccio the soil has a $\mathrm{CaCO}_{3}$ content ranging from 1.69 to $2.64 \%$ and a $\mathrm{pH}$ of $6.8-7.4$.

As production areas are often of different dimensions and their productivity varies considerably, in the experimental truffière productive plots of $300-500 \mathrm{~m}^{2}$ were selected on the basis of the confidential indications of their productivity provided by local truffle hunters and their real productivity was established over the three years of the study. A total of 39 plots (9 in Tuscany, 9 in Emilia Romagna, 9 in Molise and 12 in Abruzzo) were identified and delimited. Details of the pedological and vegetative characteristics of each experimental truffière plot are described in the project website [36-38].

\section{Assessment of truffle production}

We used trained dogs to assess truffle production every week in the T. magnatum season (September-December) for three consecutive years (2008-2010). The truffles collected were numbered, weighed and recorded for each plot.

\section{Experimental layout}

Soil cores $(1.6 \mathrm{~cm}$ diameter, $30 \mathrm{~cm}$ deep) were extracted using a disposable, cylindrical, polyvinyl chloride tube inserted inside a steel soil borer, purpose-built for this study. A set of 9 equidistant soil cores were taken from each plot along two diagonal lines, excluding a border area of $5 \mathrm{~m}$ on each side of the plot to minimize possible edge effects. Sampling was carried out in January 2009, 2010 and 2011 at the end of the annual white truffle season.

The soil cores collected from each plot were pooled together to obtain a sample per plot for each year and any root fragments, stones or organic debris were carefully removed using a stereomicroscope. A control soil sample was also collected $200 \mathrm{~m}$ outside each experimental truffière from non-productive areas. The soil was stored at $-80^{\circ} \mathrm{C}$ and then lyophilized the for three days using the Virtis Benchtop $2 \mathrm{~K}$ freeze dryer (SP Industries, Gardiner, New York). After drying, each sample was finely ground in a mortar, sieved, homogenized and stored at $-20^{\circ} \mathrm{C}$ until DNA extraction was performed.

\section{Soil DNA extraction}

A DNA extraction procedure was specifically developed for all the four types of soil analysed in this study. Three replicates (5 g each) were prepared for each soil sample, re-suspended in $6-7 \mathrm{ml}$ of CTAB lysis buffer (2\% CTAB, $2 \%$ Polyvinylpyrrolidon, $2 \mathrm{M} \mathrm{NaCl}, 20 \mathrm{mM}$ EDTA, $100 \mathrm{mM}$ Tris- $\mathrm{HCl}, \mathrm{pH}$ 8) and processed according the detailed protocol described in Additional file 2. Brown crude DNA solutions (about $3 \mathrm{ml}$ in volume) from each reaction were obtained following this extraction phase and $1 \mathrm{ml}$ aliquots were then purified using the Nucleospin Plant II kit (Macherey-Nagel, Düren, Germany) following the manufacturer's instructions with slight modifications (see Additional file 2). Total DNAs were finally eluted in $65 \mu \mathrm{l}$ of elution buffer $(5 \mathrm{mM}$ Tris/ $/ \mathrm{HCl}$, $\mathrm{pH}$ 8.5). The amount of DNA in each extract was quantified using a NanoDrop ND-1000 Spectrophotometer (Thermo Scientific). The quality of the total DNAs was evaluated with optical density (OD) 260/280 nm and 260/230 nm ratios. Extractions with OD ratios less than 1.4 and DNA quantity less than $25 \mathrm{ng} \mathrm{Il}^{-1}$ were repeated. In addition soil DNA extracts were PCRamplified with primer pair ITS1-ITS4 [39] to confirm the absence of DNA polymerase inhibitors. Extracts with positive ITS1-ITS4 amplification products (from $500 \mathrm{bp}$ to $1000 \mathrm{bp}$ ) were considered suitable for quantitative PCR (qPCR) assays. Purified DNAs were stored at $-80^{\circ} \mathrm{C}$ until processed.

\section{Primer and probe selection}

ITS1-5.8 S-ITS2 rDNA sequences of T. magnatum and other truffle species were retrieved from GenBank database (http://www.ncbi.nlm.nih.gov/; date of accession: June, 2008) and aligned with Multalign [40] to identify species-specific domains for primer and probe selection. 
Oligonucleotide design was carried out with Primer3 software (http://frodo.wi.mit.edu/primer3/) [41] with the following parameters: amplicon size 90-110, primer size $18-22$ bp (opt. $20 \mathrm{bp}$ ), melting temperature $58-62^{\circ} \mathrm{C}$ (opt. $60^{\circ} \mathrm{C}$ ), GC content $40-60 \%$ (opt. 50\%), Max Self Complementarity $=5$. Secondary structures and dimer formation were verified using Oligo Analyzer 1.0.3 software (Freeware, Teemu Kuulasmaa, Finland) and specificity was firstly evaluated in silico using BLASTN algorithm (http://blast.ncbi.nlm.nih.gov/Blast.cgi). A primer pair and the respective probe was selected for both the ITS1 and the ITS2 region (Table 2) and their specificity was then confirmed with qualitative PCR against genomic DNA of different mycorrhizal, saprobic and pathogenic fungi (Table 3). The specificity of the oligonucleotides selected as probes was tested in PCR reactions using their opposite primers (TmgITS1rev with TmgITS1prob and TmgITS2for with TmgITS2prob). Fungal DNA was isolated from fruiting bodies or mycelia using the Nucleospin Plant II kit (Macherey-Nagel) according to the manufacturer's protocol for fungi. Furthermore, the sensitivity of the selected primer pairs was assessed by amplifying T. magnatum DNA 10 -fold serial dilutions (from $10 \mathrm{ng}$ to $0.001 \mathrm{ng}$ ) in pooled genomic DNAs from the other fungal species used in this study.

Conventional PCRs were performed on $25 \mu \mathrm{l}$ reaction mixture volumes containing $100 \mathrm{ng}$ of total DNA, $10 \mathrm{mM}$ Tris- $\mathrm{HCl}$ (pH 8.3), $50 \mathrm{mM} \mathrm{KCl,} 1.5 \mathrm{mM} \mathrm{MgCl} 2,200 \mu \mathrm{M}$ for each dNTP, $400 \mathrm{nM}$ for each primer and $1.5 \mathrm{U}$ of $\mathrm{TaKaRa}^{\mathrm{TM}}$ rTaq DNA polymerase (Takara, Otsu, Japan). PCR conditions were as follow: 25 cycles of $95^{\circ} \mathrm{C}$ for $20 \mathrm{~s}$, $60^{\circ} \mathrm{C}$ for $30 \mathrm{~s}, 72^{\circ} \mathrm{C}$ for $40 \mathrm{~s}$ with an initial denaturation at $95^{\circ} \mathrm{C}$ for $6 \mathrm{~min}$ and a final extension at $72^{\circ} \mathrm{C}$ for $7 \mathrm{~min}$. PCR products were electrophoresed in $1 \%$ agarose gels and visualized by staining with ethidium bromide in a GeneGenius Imaging System (SynGene, Cambridge, UK).

\section{Real-time PCR}

TaqMan PCR assays were carried out in 96-well optical plates (Bioplastic) using a Stratagene Mx3000P QPCR system (Stratagene, La Jolla, CA, USA). Each amplification was performed on $25-\mu \mathrm{l}$ reaction volumes containing $12.5(1 \mathrm{X}) \mu \mathrm{l}$ of Maxima Probe qPCR Master mix (Fermentas), $30 \mathrm{nM}$ of ROX and $200 \mathrm{ng}$ of total DNA. Primer and probe concentration were optimised to $0.5 \mu \mathrm{M}$ and $0.2 \mu \mathrm{M}$ respectively based on the lowest threshold cycle $\left(\mathrm{C}_{\mathrm{t}}\right)$ values and the highest fluorescent signal. The TaqMan probe was labelled at the 5'end with the fluorescent reporter dye FAM (6-carboxy-fluorescin) while the 3 ' end was modified with the quencher dye TAMRA (6-carboxy-tetramethylrhodamine) (MWG BIOTECH, Ebersberg, Germany). Two replicates per soil sample and no template controls were prepared for each plate and Real-time PCRs were repeated twice to confirm the results.

The optimised thermal cycle protocol included a 10 min incubation at $95^{\circ} \mathrm{C}$ followed by 45 cycles of $95^{\circ} \mathrm{C}$ for $15 \mathrm{~s}, 60^{\circ} \mathrm{C}$ for $30 \mathrm{~s}$ and $72^{\circ} \mathrm{C}$ for $30 \mathrm{~s}$. The threshold fluorescence level was determined with the default adaptive baseline algorithm of the MXPro software (version 4.10) (Agilent technologies) and the resulting $C_{t}$ values were automatically converted to quantities of $T$. magnatum DNA using the standard curve method. A standard curve was generated for each run with a series of tenfold dilutions of genomic DNA from $T$. magnatum (from $10^{7}$ to $10^{2} \mathrm{fg}$ per reaction) as standards. To evaluate the real-time PCR detection limit further serial dilutions of 1 and $10 \mathrm{fg}$ of T. magnatum DNA were tested in triplicate. All real-time PCR products were electrophoresed as described above to exclude amplification of non-target sequences.

\section{Data analysis}

ANOVA was applied to check for significant differences in the amount of DNA extracted and the T. magnatum DNA concentrations obtained from the different trufféres. When significant differences were encountered, mean values were compared using Bonferroni's test. The non-parametric Kruskal-Wallis test was used to verify the results obtained with the ANOVA. Spearman's rank correlation coefficient was calculated to determine correlations between $T$. magnatum DNA concentration and truffle production (ascoma number and weight). The significance level was set at the $5 \%$ probability level. Statistical analyses were performed using XLSTAT- Pro 7.5 (Addinsoft, Paris, France).

\section{Additional files}

Additional file 1: Number and weight of ascomata. This file contains a table showing the number and weight of the ascomata found in the experimental plots of the four truffières over the three years of survey (2008-2009-2010).

Additional file 2: DNA extraction protocol. This file contains the detailed protocol developed in this study for the extraction of genomic DNAs from $5 \mathrm{~g}$ soil samples.

\section{Abbreviation}

OD: Optical density; ITS: Internal transcribed spacer; Asl: Above sea level; CTAB: Cetyl Trimethyl Ammonium Bromide;

EDTA: Ethylenediaminetetraacetic acid disodium salt; $C_{t}$ : Threshold cycle; FAM: 6-carboxy-fluorescin; TAMRA: 6-carboxy-tetramethylrhodamine.

\section{Competing interests}

The authors declare that they have no competing interests.

\section{Authors' contributions}

MI participated in the design of the study, perfected the DNA extraction method, processed and analysed Emilia Romagna and Tuscany samples, performed Real Time analyses and helped to draft the manuscript. ML contributed in coordination of the study and helped in processing Molise 
and Abruzzo samples. MO processed and analysed Molise and Abruzzo samples. ES participated in processing Tuscany samples and carried out the statistical analyses. EB helped to perform Real Time analyses and to analyse the data. AZ participated in the study conception and coordination and drafted the manuscript. All authors read and approved the final version of the manuscript.

\section{Acknowledgements}

This work was financially supported by the Tuscany, Emilia Romagna, Abruzzo and Molise regions (project MAGNATUM - Monitoraggio delle Attività di Gestione delle tartufaie NAturali di TUber Magnatum). The project MAGNATUM was coordinated by ARSIA (Agenzia Regionale per lo Sviluppo e L'Innovazione nel settore Agricolo-forestale) of Tuscany region. The Authors would like to thank Dr lan Hall for the critical reading of the introduction and discussion sections and Dr. Enrico Lancellotti for the helpful suggestions concerning statistical analyses. We are grateful to the Dr. Claudia Perini and the Prof Giovanni Pacioni for the local coordination of this research.

\section{Author details}

'Dipartimento di Protezione e Valorizzazione Agroalimentare, Alma Mater Studiorum Università di Bologna, via Fanin 46, 40127, Bologna, Italy. ²Dipartimento di Scienze Ambientali, Università dell'Aquila, via Vetoio, Coppito 1, 67100, L'Aquila, Italy. ${ }^{3}$ Dipartimento di Scienze Ambientali "G. Sarfatti", Università degli Studi di Siena, via Mattioli 4, 53100, Siena, Italy.

Received: 22 December 2011 Accepted: 14 May 2012

Published: 6 June 2012

\section{References}

1. Hall I, Brown GT, Zambonelli A: Taming the Truffle. Portland: Timber Press; 2007.

2. Glamočlija J, Vujičić R, Vukojević J: Evidence of truffles in Serbia. Mycotaxon 1997, 65:211-222.

3. Ceruti A, Fontana A, Nosenzo C: Le specie europee del genere Tuber: una revisione storica. Monografie $n^{\circ}$ 37. Torino: Museo Regionale di Scienze Naturali; 2003.

4. Gogan A: Studies on cultivation possibilities of summer truffle (Tuber aestivum Vittad.) and smooth black truffle (Tuber macrosporum Vittad.) in Hungary. PhD thesis, Gödöllő University, Institute of Horticultural Technologies, 2011. [http://www.szie.hu/file/tti/archivum/csorbaine_thezis. pdf].

5. Mello A, Fontana A, Meotto F, Comandini O, Bonfante P: Molecular and morphological characterization of Tuber magnatum mycorrhizas in a long-term survey. Microbiol Res 2001, 155:279-284

6. Rubini A, Paolocci F, Granetti B, Arcioni S: Morphological characterization of molecular-typed Tuber magnatum ectomycorrhizae. Mycorrhiza 2001, 11:179-185.

7. Rubini A, Riccioni C, Arcioni S, Paolocci F: Troubles with truffles: unveiling more of their biology. New Phytol 2007, 174:256-259.

8. Buee M, Martin F: Method for obtaining Tuber magnatum mycelium and mycelium obtained by means of the method. Pub. No.: WO/2009/136049 International Application No.: PCT/FR2009/050582 [http://www.wipo.int/ patentscope/search/en/WO2009136049].

9. Bencivenga $M$, Di Massimo G, Donnini D, Baciarelli Falini L: The cultivation of truffles in Italy. Acta Botanica Yunnanica 2009, 16(Suppl 16):100-102.

10. Gregori G: Problems and expectations with the cultivation of Tuber magnatum. In Proceedings of the Second International Conference on Edible Mycorrhizal Mushrooms: 3-5 July 2001; Christchurch. Edited by lan R.: Hall, Yun Wang, Eric Danell, Alessandra Zambonelli: Institute for Crop and Food Research Limited; 2001. CD Room.

11. Hall IR, Zambonelli A, Primavera F: Ectomycorrhizal fungi with edible fruiting bodies. 3. Tuber magnatum. Econ Bot 1998, 52:192-200.

12. Hall IR, Yun W, Amicucci A: Cultivation of edible ectomycorrhizal mushrooms. Trends Biotechnol 2003, 21(10):433-438.

13. Bertini L, Rossi I, Zambonelli A, Amicucci A, Sacchi A, Cecchini M, Gregori G, Stocchi V: Molecular identification of Tuber magnatum ectomycorrhizae in the field. Microbiol Res 2005, 161:59-64.

14. Murat C, Vizzini A, Bonfante P, Mello A: Morphological and molecular typing of the below-ground fungal community in a natural Tuber magnatum truffle-ground. FEMS Microbiol Lett 2005, 245:307-313.
15. Zampieri E, Murat C, Cagnasso M, Bonfante P, Mello A: Soil analysis reveals the presence of an extended mycelial network in a Tuber magnatum truffle ground. FEMS Microbiol Ecol 2010, 71:43-49.

16. Chemidlin Prévost-Bouré N, Christen R, Dequiedt S, Mougel C, Lelièvre M, Claudy Jolivet C, Shahbazkia HR, Guillou L, Arrouays D, Ranjard L: Validation and application of a PCR primer set to quantify fungal communities in the soil environment by real-time quantitative PCR. PLoS One 2011, 6(9): e24166. doi:10.1371/journal.pone.0024166.

17. Landeweert R, Veenman C, Kuyper TW, Fritze H, Wernars K, Smit E: Quantification of ectomycorrhizal mycelium in soil by real-time PCR compared to conventional quantification techniques. FEMS Microbiol Ecol 2003, 45:283-292.

18. Kennedy PG, Bergemann SE, Hortal S, Bruns TD: Determining the outcome of field-based competition between two Rhizopogon species using real-time PCR. Mol Ecol 2007, 16:881-890.

19. Parladé J, Hortal S, Pera J, Galipienso L: Quantitative detection of Lactarius deliciosus extraradical soil mycelium by real-time PCR and its application in the study of fungal persistence and interspecific competition. $J$ Biotechnol 2007, 128:14-23.

20. Suz LM, Martin MP, Oliach D, Fischer CR, Colinas C: Mycelial abundance and other factors related to truffle productivity in Tuber melanosporum-Quercus ilex orchards. FEMS Microbiol Lett 2008, 285:72-78.

21. Suz LM, Martın MP, Colinas C: Detection of Tuber melanosporum DNA in soil. FEMS Microbiol Lett 2006, 254:251-257.

22. Gryndler M, Hršelová H, Soukupová L, Streiblová E, Valda S, Borovička J, Gryndlerová H, Gažo J, Miko M: Detection of summer truffle (Tuber aestivum Vittad.) in ectomycorrhizae and in soil using specific primers. FEMS Microbiol Lett 2011, 318:84-89.

23. Feinstein LM, Sul WJ, Blackwood CB: Assessment of bias associated with incomplete extraction of microbial DNA from soil. Appl Environ Microbio 2009, 75:5428-5433.

24. Ranjard L, Lejon DP, Mougel C, Schehrer L, Merdinoglu D, Chaussod R: Sampling strategy in molecular microbial ecology: influence of soil sample size on DNA fingerprinting analysis of fungal and bacterial communities. Environ Microbiol 2003, 5:1111-1120.

25. Braid MD, Daniels $L M$, Kitts $C L$ : Removal of $P C R$ inhibitors from soil DNA by chemical flocculation. J Microbiol Meth 2003, 52:389-393.

26. Yankson KK, Steck TR: Strategy for extracting DNA from clay soil and detecting a specific target sequence via selective enrichment and real-time (quantitative) PCR amplification. Appl Environ Microbiol 2009, 75:6017-6021

27. Cai P, Huang Q, Zhang X, Chen H: Adsorption of DNA on clay minerals and various colloidal particles from an Alfisol. Soil Biol Biochem 2006, 38:471-476.

28. De la Varga H, Águeda B, Martínez-Peña F, Parladé J, Pera J: Quantification of extraradical soil mycelium and ectomycorrhizas of Boletus edulis in a Scots pine forest with variable sporocarp productivity. Mycorrhiza 2011, doi:10.1007/s00572-011-0382-2.

29. Bridge P, Spooner BM: Soil fungi: diversity and detection. Plant Soil 2001, 232:47-154

30. Nilsson RH, Kristiansson E, Ryberg M, Hallenberg N, Larsson KH: Intraspecific ITS variability in the kingdom fungi as expressed in the international sequence databases and Its implications for molecular species identification. Evol Bioinform 2008, 4:193-201.

31. Iotti M, Amicucci A, Bonito G, Bonuso E, Stocchi V, Zambonelli A: Selection of a set of specific primers for the identification of Tuber rufum: a truffle species with high genetic variability. FEMS Microbiol Lett 2007, 277:223-231.

32. Mello A, Murat C, Vizzini A, Gavazza V, Bonfante P: Tuber magnatum Pico, a species of limited geographical distribution: its genetic diversity inside and outside a truffle ground. Environ Microbiol 2005, 7:55-65.

33. Murat C, Díez J, Luis P, Delaruelle C, Dupré C, Chevalier G, Bonfante P, Martin F: Polymorphism at the ribosomal DNA ITS and its relation to postglacial re-colonization routes of the Perigord truffle Tuber melanosporum. New Phytol 2004, 164:401-411.

34. Wedén C, Danell E, Camacho FJ, Backlund A: The population of the hypogeous fungus Tuber aestivum syn. T. uncinatum on the island of Gotland. Mycorrhiza 2004, 14:19-23.

35. Bonuso E, Zambonelli A, Bergemann S, lotti M, Garbelotto M: Multilocus phylogenetic and coalescent analyses identify two cryptic species in the 
Italian bianchetto truffle, Tuber borchii Vittad. Conserv Genet 2010,

11:1453-1466.

36. Frignani F: Analisi floristico-vegetazionale delle tartufaie sperimentali situate in Toscana ed Emilia Romagna. [http://www.agrsci.unibo.it/ magnatum/home.htm $>$ Risultati $>$ Analisifloristiche-vegetazionali $>$ Emilia Romagna e Toscana].

37. Ciaschetti G: Analisi floristico-vegetazionale delle tartufaie sperimentali situate in Abruzzo ed in Molise. [http://www.agrsci.unibo.it/magnatum/ home.htm > Risultati > Analisi floristiche - vegetazionali > Abruzzo - Molise].

38. Gardin L, Paolanti M: Le caratteristiche dei suoli delle tartufaie naturali oggetto di sperimentazione nel progetto MAGNATUM. [http://www agrsci.unibo.it/magnatum/home.htm $>$ Risultati $>$ Analisi pedologiche $>$ Emilia Romagna e Toscana].

39. White TJ, Bruns T, Lee S, Taylor J: Amplification and direct sequencing of fungal ribosomal RNA genes for phylogenetics. In PCR Protocol: A Guide to Methods and Applications. Edited by Innis MA, Gelfand DH, Sninsky JJ, White TJ. S. Diego: Academic; 1990:315-322.

40. Corpet F: Multiple sequence alignment with hierarchical clustering. Nucleic Acids Res 1988, 16:10881-10890.

41. Rozen S, Skaletsky HJ: Primer3 on the WWW for general users and for biologist programmers. In Bioinformatics Methods and Protocols: Methods in Molecular Biology. Edited by Krawetz S, Misener S. Totowa: Humana Press; 2000:365-386.

doi:10.1186/1471-2180-12-93

Cite this article as: lotti et al:: Development and validation of a real-time PCR assay for detection and quantification of Tuber magnatum in soil. BMC Microbiology 2012 12:93.

\section{Submit your next manuscript to BioMed Central and take full advantage of:}

- Convenient online submission

- Thorough peer review

- No space constraints or color figure charges

- Immediate publication on acceptance

- Inclusion in PubMed, CAS, Scopus and Google Scholar

- Research which is freely available for redistribution 